\title{
SIKAP SISWA SMA DI KOTA BANDUNG TERHADAP INFORMASI MENGENAI PROGRAM STUDI DI PERGURUAN TINGGI NEGERI INDONESIA
}

\author{
Oleh \\ Meria Octavianti dan Putri Trulline \\ Program Studi Manajemen Komunikasi Universitas Padjadjaran
}

\begin{abstract}
ABSTRAK
Ketidakpastian akan dialami oleh setiap siswa SMA, khususnya Kelas XII yang akan segera mengakhiri masa studinya di jenjang pendidikan menengah atas. Mereka harus menatap jauh ke depan, menentukan pilihan mengenai program studi yang akan mereka pilih ketika mereka melanjutkan pendidikan ke jenjang yang lebih tinggi. Di Indonesia, khususnya Kota Bandung, perguruan tinggi negeri masih menjadi pilihan favorit bagi para siswa SMA. Jumlah perguruan tinggi negeri yang tidak sebanding dengan banyaknya calon mahasiswa, menjadikan persaingan yang sangat ketat di antara sesama pendaftar. Informasi yang tepat dan lengkap diperlukan untuk penentuan sikap dalam pegambilan keputusan pemilihan program studi.

Berdasarkan paparan di atas, maka penelitian ini berusaha untuk mengungkap sikap siswa SMA di Kota Bandung terhadap informasi mengenai perguruan tinggi negeri. Metode yang akan digunakan dalam penelitian ini adalah metode penelitian kuantitatif dengan teknik survey. Kuesioner akan digunakan untuk mendapatkan data primer, dan wawancara serta kajian pustaka untuk mendapatkan data sekunder. Populasi dalam penelitian ini adalah siswa SMA Negeri Kelas XII di Kota Bandung, dimana Multistage Cluster Sampling digunakan untuk menentukan sampel penelitian.

Hasil penelitian menunjukkan bahwa secara khusus, media yang paling banyak memberikan kontribusi mengenai informasi program studi adalah website resmi perguruan tinggi tersebut. Tetapi secara umum, media interpersonal masih memberikan kontribusi yang relatif tinggi dalam pencarian informasi program studi oleh siswa SMA Kelas XII. Dengan adanya informasi yang disampaikan melalui berbagai media, baik interpersonal, massa, maupun internet, pengetahuan (kognitif) dan keyakinan (afektif) siswa SMA Kelas XII mengenai program studi yang akan mereka pilih menjadi tinggi. Kondisi tersebut cenderung mendorong mereka untuk memilih program studi yang sesuai dengan minat dan harapan mereka.
\end{abstract}

Kata kunci: sikap, pencarian informasi, siswa SMA

\section{Pendahuluan}

Di Indonesia, terdapat banyak program studi yang ditawarkan oleh perguruan tinggi, baik perguruan tinggi negeri maupun perguruan tinggi swasta. Banyaknya pilihan program studi berkorelasi dengan kemungkinan para siswa SMA Kelas XII yang notabene merupakan calon mahasiswa untuk dapat memilih program studi yang sesuai dengan minat dan citacitanya. Tetapi di sisi lain, banyaknya pilihan tersebut ternyata menyebabkan ketidakpastian 
yang tinggi bagi calon mahasiswa. Mereka berada pada kondisi tidak pasti untuk menentukan program studi yang tepat untuk dirinya.

Selain itu, pola pemilihan program studi, khususnya untuk program studi yang ditawarkan oleh Perguruan Tinggi Negeri di Indonesia, seringkali mengalami perubahan. Pada tahun 2016 ini, pola pemilihan program studi yang diberlakukan adalah berdasarkan pada Peraturan Menteri Riset, Teknologi, dan Pendidikan Tinggi Nomor 45 Tahun 2015. Dimana peraturan tersebut merupakan perubahan atas Permenristekdikti Nomor 2 Tahun 2015 tentang Penerimaan Mahasiswa Baru Program Sarjana pada Perguruan Tinggi Negeri. Menurut peraturan tersebut, pola penerimaan mahasiswa baru program Sarjana dilakukan melalui: Seleksi Nasional Masuk Perguruan Tinggi Negeri (SNMPTN), Seleksi Bersama Masuk Perguruan Tinggi Negeri (SBMPTN), dan Seleksi Mandiri. SBMPTN 2016 adalah seleksi yang dilakukan oleh PTN secara bersama di bawah koordinasi Panitia Pusat dengan seleksi berdasarkan hasil ujian tertulis dalam bentuk cetak (Paper Based Testing) atau menggunakan komputer (Computer Based Testing), atau kombinasi hasil ujian tertulis dan ujian keterampilan calon mahasiswa ${ }^{1}$. Pola pemilihan ini, belum tentu sama dengan apa yang akan terjadi pada tahun-tahun selanjutnya.

Banyaknya jumlah program studi yang ditawarkan oleh Perguruan Tinggi Negeri dan tersedianya beberapa pola penerimaan mahasiswa program sarjana di Perguruan Tinggi Negeri mengharuskan calon mahasiswa untuk dapat menentukan pilihan program studi yang tepat pada setiap jenis pola penerimaan mahasiswa baru.

Memilih program studi di jenjang sarjana bukanlah hal yang mudah. Memilih secara tergesa-gesa tanpa memperhitungkan segala aspek akan berakibat fatal, karena salah memilih program studi akan berdampak besar pada masa depan seorang siswa lulusan SMA. Maka diperlukan strategi yang tepat dalam memilih program studi. Ada beberapa aturan teknik dalam pemilihan program studi di SBMPTN 2016, yaitu (1) Peserta dapat memilih program studi sebanyak-banyaknya 3 (tiga) program studi, (2) Peserta ujian yang hanya memilih 1 (satu) program studi dapat memilih program studi di PTN manapun, (3) Peserta ujian yang memilih 2 (dua) program studi atau lebih, salah satu pilihan program studi tersebut harus di PTN yang berada dalam satu wilayah dengan tempat peserta mengikuti ujian. Pilihan program studi yang lain dapat di PTN di luar wilayah tempat peserta mengikuti ujian.

Mengetahui teknik yang tepat dalam memilih program studi tidaklah cukup bagi para lulusan SMA untuk dapat memperoleh program studi yang tepat. Para calon peserta juga

${ }^{1}$ Dikutip dari https://sbmptn.ac.id/?mid=13 pada tanggal 23 Mei 2016 pukul 12.35WIB 
harus megetahui dan memahami mengenai strategi memilih program studi pada SBMPTN 2016 ini, agar tidak salah memilih program studi dan tidak berakibat fatal kedepannya. Berikut 6 cara tepat memilih jurusan kuliah di Perguruan Tinggi Negeri yaitu (1) sesuaikan dengan cita-cita, (2) sesuaikan dengan minat dan bakat, (3) mencari informasi yang sempurna, (4) perkirakan biaya yang akan dikeluarkan, (4) pertimbangan daya tampung atau peluang diterima di dalam program studi yang akan dipilih, (5) pertimbangkan masa depan karir dan pekerjaan yang diinginkan ${ }^{2}$.

Paparan di atas menunjukkan bahwa setiap siswa SMA yang akan melanjutkan studi ke perguruan tinggi negeri harus melakukan persiapan yang baik agar dapat lulus di program studi yang diinginkan. Salah satu masalah yang umum dialami siswa yang baru lulus dari sekolah menengah atas adalah kurangnya informasi mengenai program studi di Perguruan Tinggi Negeri sehingga tidak sedikit yang merasa bingung memilih program studi. Tak jarang pula mereka akhirnya terjebak dalam program studi yang salah, dalam arti bisa saja program studi yang mereka ambil ternyata tidak sesuai dengan bakat atau minat mereka, tidak sesuai dengan anggaran biaya orangtua, atau bahkan pada akhirnya menyebabkan mereka kesulitan dalam memperoleh pekerjaan setelah tamat kuliah.

Ketidakpastian akan dialami oleh setiap siswa SMA, khususnya Kelas XII yang akan segera mengakhiri masa studinya di jenjang pendidikan menengah atas. Mereka harus menatap jauh ke depan, menentukan pilihan mengenai program studi yang akan mereka pilih ketika mereka melanjutkan pendidikan ke jenjang yang lebih tinggi. Di Indonesia, khususnya Kota Bandung, perguruan tinggi negeri masih menjadi pilihan favorit bagi para siswa SMA. Selain dikarenakan kualitas yang baik, prestise juga menjadi faktor pendorong siswa SMA untuk dapat melanjutkan pendidikan di perguruan tinggi negeri. Keberhasilan lolos seleksi dari jumlah pendatar yang sangat banyak dan berasal dari seluruh pelosok negeri, menjadikan kebanggaan tersendiri bagi siswa SMA untuk dapat menjadi mahasiswa perguruan tinggi negeri di Kota Bandung.

Jumlah perguruan tinggi negeri yang tidak sebanding dengan banyaknya calon mahasiswa, menjadikan persaingan yang sangat ketat di antara sesama pendafar. Banyaknya program studi favorit yang menjadi incaran siswa SMA menjadikan mereka harus mengantisipasi tingkat kemungkinan keberhasilan mereka untuk bisa menjadi mahasiswa di program studi favorit tersebut. Antisipasi dapat dilakukan dengan menyediakan berbagai pilihan program studi alternatif, di luar program studi yang menjadi incaran tersebut. 
Walaupun pilihan lain, tetapi akan jauh lebih baik apabila program studi alternatif tersebut tetap meerupakan program studi yang memang diminati dan sesuai dengan passion dari calon mahasiswa tersebut. Bukan hanya alternatif pilihan program studi, tetapi alternatif perguruan tinggi pun harus dipertimbangkan.

Perguruan tinggi swasta, dari segi kuantitas jumlahnya sangat banyak. Begitu pula dari segi kualitas. Terdapat perguruan tinggi swasta di Kota Bandung yang memiliki kualitas yang tidak kalah baik bahkan jauh lebih baik dibandingkan dengan perguruan tinggi negeri. Hanya saja, jumlah perguruan tinggi swasta yang sangat banyak ini, dapat memberikan distorsi informasi bagi para calon mahasiswa. Banyak jumlah informasi yang diterima, belum tentu berdampak positif bagi calon mahasiswa. Tingkat ketidakpastian menjadi semakin tinggi. Para siswa SMA semakin sulit untuk menentukan pilihannya. Mereka membutuhkan sumber informasi yang memiliki tingkat keterpercayaan yang tinggi dalam memberikan informasi mengenai proagram studi di perguruan tinggi, agar mampu mengatasi ketidakpastian tersebut. Berdasarkan paparan di atas, maka dalam penelitian ini berusaha untuk mengungkap sikap siswa SMA di Kota Bandung terhadap informasi mengenai program studi di perguruan tinggi.

\section{Tinjauan Pustaka}

\section{Sikap}

Sikap merupakan aspek penting yang menarik untuk diteliti dalam kehidupan sosial. Sikap dapat dilihat sebagai keadaan di dalam diri sesorang yang mampu menggerakkan orang tersebut untuk bertindak atau berbuat dengan perasaan tertentu dalam menanggapi berbagai objek atau situasi yang terjadi di lingkungan sosialnya. Sikap dapat memberikan kesiapan merespon secara positif ataupun negatif terhadap objek atau situasi tersebut.

Banyak sekali definisi yang disampaikan para ahli mengenai apa itu sikap. Sarnoff (dalam Sarwono, 2000) menyatakan sikap sebagai kesediaan untuk bereaksi (disposition to react) secara positif (favorably) atau secara negatif (unfavorably) terhadap obyek - obyek tertentu. Sedangkan La Pierre (dalam Azwar, 2003) memberikan definiusi bahwa sikap merupakan suatu pola perilaku, tendensi atau kesiapan antisipatif, predisposisi untuk menyesuaikan diri dalam situasi sosial, atau secara sederhana, sikap adalah respon terhadap stimuli sosial yang telah terkondisikan. Lebih lanjut Soetarno (1994) memberikan definisi sikap adalah pandangan atau perasaan yang disertai kecenderungan untuk bertindak terhadap obyek tertentu. Sikap senantiasa diarahkan kepada sesuatu artinya tidak ada sikap tanpa 
obyek. Sikap diarahkan kepada benda-benda, orang, peritiwa, pandangan, lembaga, norma dan lain-lain.

Meskipun banyak sekali pendapat yang menyatakan mengenai definsi sikap, tetapi yang perlu digarisbawahi adalah sikap tidak dapat berdiri sendiri. Sikap haruslah diikuti oleh kata "terhadap", atau "pada" objek sikap. Bila ada orang yang berkata "sikap saya positif," kita harus mempertanyakan "sikap terhadap apa atau siapa?". Selain itu, Rahmat juga menambahkan bahwa sikap mengandung aspek evaluatif: artinya mengandung nilai menyenangkan atau tidak menyenangkan. Selain itu, sikap timbul dari pengalaman; tidak dibawa sejak lahir, tetapi merupakan hasil belajar. Karena itu sikap dapat diperteguh atau diubah. (Rahmat, 2001:40).

\section{Fungsi Sikap}

Fungsi sikap sendiri dikemukakan oleh Katz, dimana dijelaskan bahwa untuk memahami bagaiman suatu sikap dapat menerima ataupun menolak suatu stimuli harus berdasarkan pada dasar motivasional dari sikap seseorang. Menurut Katz, motivasional sikap inilah yang merupakan fungsi sikap bagi seseorang. Katz merumuskan fungsi sikap ke dalam empat macam, yaitu: (Azwar, 1995 : 53-55).

Fungsi Instrumental, Fungsi Penyesuaian, atau Fungsi Manfaat. Fungsi ini menyatakan bahwa individu dengan sikapnya berusaha untuk memaksimalkan hal-hal yang diinginkan dan meminimalisir hal yang tidak diinginkan. Individu akan membentuk sikap positif terhadap hal yang dirasakannya akan mendatangkan keuntungan dan membentuk sikap negatif terhadap hal yang dirasakannya mendatangkan kerugian.

Fungsi Pertahanan Ego. Sikap akan menjadi suatu pertahanan ego jika pada waktu tertentu seseorang merasakan atau mengalami hal yang tidak menyenangkan dan mengancam egonya. Disini sikap akan melindungi seseorang dari kenyataan yang pahit tersebut.

Fungsi Pernyataan Nilai. Fungsi sikap akan membuat seseorang mengembangkan sikap tertentu untuk memperoleh kepuasan dalam menyatakan nilai yang dianutnya sesuai dengan pengalaman pribadi dan konsep-konsepnya. Seseorang akan menjadikan sikap sebagai suatu saran ekspresi nilai netral yang berasal dalam dirinya.

Fungsi pengetahuan. Fungsi sikap sebagai pengetahuan menjelaskan bahwa pada dasarnya manusia mempunyai dorongan untuk ingin tahu terhadap suatu hal. Banyaknya hal yang belum diketahui oleh seorang manusia akan membuatnya berusaha untuk menyusun, menata kembali, atau mengubah sedemekian rupa sehingga suatu konsistensi. Jadi, dapat 
dikatakan sikap berperan sebagai suatu skema, dimana sikap digunakan untuk melakukan evaluasi terhadap fenomena luar yang ada dan mengubahnya sehingga dunia menjadi tampak logis dan masuk akal.

\section{Faktor-faktor yang Mempengaruhi Pembentukan Sikap}

Beberapa faktor yang mempengaruhi pembentukkan sikap adalah (1) Pengalaman pribadi. Untuk dapat menjadi dasar pembentukan sikap, pengalaman pribadi harus meninggalkan kesan yang kuat. Karena itu, sikap akan lebih mudah terbentuk apabila pengalaman pribadi tersebut melibatkan faktor emosional. Dalam situasi yang melibatkan emosi, penghayatan akan pengalaman akan lebih mendalam dan lebih lama berbekas. (2) Kebudayaan. B.F. Skinner (dalam, Azwar 1995) menekankan pengaruh lingkungan (termasuk kebudayaan) dalam membentuk kepribadian seseorang. Kepribadian tidak lain daripada pola perilaku yang konsisten yang menggambarkan sejarah reinforcement (penguatan, ganjaran) yang dimiliki. Pola reinforcement dari masyarakat untuk sikap dan perilaku tersebut, bukan untuk sikap dan perilaku yang lain. (3) Orang lain yang dianggap penting. Pada umumnya, individu bersikap konformis atau searah dengan sikap orang orang yang dianggapnya penting. Kecenderungan ini antara lain dimotivasi oleh keinginan untuk berafiliasi dan keinginan untuk menghindari konflik dengan orang yang dianggap penting tersebut. (4) Media Massa. Sebagai sarana komunikasi, berbagai media massa seperti televisi, radio, mempunyai pengaruh besar dalam pembentukan opini dan kepercayaan orang. Adanya informasi baru mengenai sesuatu hal memberikan landasan kognitif baru bagi terbentuknya sikap terhadap hal tersebut. Pesan-pesan sugestif yang dibawa informasi tersebut, apabila cukup kuat, akan memberi dasar afektif dalam mempersepsikan dan menilai sesuatu hal sehingga terbentuklah arah sikap tertentu. (5) Institusi Pendidikan dan Agama. Sebagai suatu sistem, institusi pendidikan dan agama mempunyai pengaruh kuat dalam pembentukan sikap dikarenakan keduanya meletakkan dasar pengertian dan konsep moral dalam diri individu. Pemahaman akan baik dan buruk, garis pemisah antara sesuatu yang boleh dan tidak boleh dilakukan, diperoleh dari pendidikan dan dari pusat keagamaan serta ajaran-ajarannya. (6) Faktor Emosi dalam Diri.Tidak semua bentuk sikap ditentukan oleh situasi lingkungan dan pengalaman pribadi seseorang. Kadang-kadang, suatu bentuk sikap merupakan pernyataan yang didasari oleh emosi yang berfungsi sebagai semacam penyaluran frustasi atau pengalihan bentuk mekanisme pertahanan ego. Sikap demikian bersifat sementara dan segera berlalu begitu frustasi telah hilang akan tetapi dapat pula merupakan sikap yang lebih 
persisten dan lebih tahan lama. contohnya bentuk sikap yang didasari oleh faktor emosional adalah prasangka.

\section{Komponen Sikap}

Menurut Rahmat (2001 : 40), memaparkan bahwa sikap bangun oleh tiga komponen yang ada di dalam diri manusia. Komponen tersebut terdiri dari komponen kognitif, afektif, dan konatif. Komponen kognitif yakni bagaimana kepercayaan terhadap objek sikap, komponen afektif yakni bagaimana perasaan terhadap objek sikap, sedangkan komponen konatif terdiri dari kebiasaan dan kemauan. Berikut merupakan penjelasan dari ketiga komponen tersebut menurut Crutchfield \& Ballachey (1982).

Komponen Kognitif. Komponen kognitif dari suatu sikap terdiri dari keyakinankeyakinan individu mengenai suatu obyek. Kognitif yang paling penting yang menentukan sikap individu adalah keyakinan evaluatif yang memberi atribusi kualitas terhadap obyek itu, seperti apakah obyek tersebut menguntungkan atau tidak, baik atau buruk. Komponen kognitif ini juga dapat mencakup keyakinan individu tentang cara merespon yang pantas atau tak pantas terhadap obyek. Jadi komponen kognitif dan komponen kecenderungan tindakan dapat berkaitan erat dengan pengalaman individu, pengamatannya serta informasi yang diperolehnya mengenai sikap.

Komponen Afektif. Komponen afektif dari satu sikap mengacu pada emosi yang terkait dengan obyek - apakah obyek itu dirasakan menyenangkan atau tidak, disukai atau tidak. Bobot emosi inilah yang memberi karakter motivasi kepada sikap.

Komponen Konatif. Komponen konatif dari suatu sikap mencakup semua kesiapan perilaku (behavioral readiness) yang terkait dengan sikap. Jika seorang individu memiliki sikap positif terhadap obyek tertentu, dia akan memiliki kecenderungan untuk membantu atau mengganjar atau mendukung obyek itu; jika dia bersikap negatif, dia akan cenderung mencelakai atau menghukum atau menghancurkan obyek tersebut.

\section{Metode dan Teknik Penelitian}

Penelitian mengenai sikap siswa SMA di Kota Bandung terhadap informasi mengenai program studi di perguruan tinggi merupakan penelitian kuantitatif, yaitu suatu proses menemukan pengetahuan yang menggunakan data berupa angka sebagai alat untuk menemukan keterangan mengenai apa yang ingin kita ketahui (Margono, 2010). Sedangkan metode yang digunakan adalah metode survey yang bersifat ekplanatoris. Informasi dalam penelitian survey dikumpulkan dari responden dengan menggunakan kuesioner. Umumnya 
pengertian survei dibatasi pada penelitian yang datanya dikumpulkan dari sampel atas populasi untuk mewakili seluruh populasi. Dengan demikian penelitian survei adalah penelitian yang mengambil sampel dari satu populasi dan menggunakan kuesioner sebagai pengumpulan data yang pokok (Singarimbun, 2006)

Teknik pengumpulan data dalam penelitian ini dilakukan dengan menggunakan kuesioner, yang didukung dengan wawancara dan observasi. Populasi dalam penelitian ini adalah seluruh siswa Kelas XII di Kota Bandung, sedangkan sampelnya adalah seluruh siswa kelas XII yang terpilih dengan menggunakan teknik multistage cluster sampling. Adapun teknik sampling ini akan dilakukan dengan mengkluster seluruh SMA Negeri di Kota Bandung yang dibagi dalam beberapa rayon.

Data primer dalam penelitian ini diperoleh dari kuesioner, sedangkan data sekunder diperoleh dari wawancara yang dilakukan kepada beberapa siswa SMA yang menjadi sampel penelitian. Selain itu, observasi juga dilakukan peneliti terhadap beberapa media yang menyajikan informasi mengenai program-program studi yang terdapat di Perguruan Tinggi Negeri. Studi Literatur tidak lupa dilakukan peneliti untuk memperoleh data tambahan yang dapat memperkuat analisis dari data-data primer yang diperoleh dalam penelitian ini.

Teknik analisis data yang digunakan pada penelitian ini adalah teknik analisis deskriptif. Menurut Azwar (1997:126), teknik analisis deskriptif bertujuan untuk memberikan deskripsi mengenai obyek penelitian berdasarkan data dan variabel yang diperoleh dari kelompok subyek yang diteliti, dan tidak dimaksudkan untuk pengujian hipotesis.

Data yang diperoleh dari pengisian kuesioner oleh para responden dianalisis dengan menggunakan teknik analisis deskriptif yaitu dikelompokkan berdasarkan jenis pertanyaannya, ditabulasikan, kemudian dianalisis secara mendalam. Uji validitas dilakukan dengan mengunakan dengan koefisien korelasi item-total(Corrected Item Total-Correllation) sedangkan uji reliabilitas dalam penelitian ini diukur berdasarkan koefisien reliabilitas Alpha Cornbach. Data yang diperoleh dari penelitian ini akan disajikan dalam bentuk paparan. Dimana paparan tersebut merupakan jawaban responden atas sejumlah pertanyaan atau pernyataan yang diajukan dalam kuesioner. Selain itu, untuk mempermudah peneliti dalam menganalisis dan memberi gambaran situasi secara jelas, data penelitian akan disajikan juga dengan menggunakan bagan, tabel, dan grafik. Setelah dipaparkan, kemudian peneliti melakukan penarikan kesimpulan dari penelitian ini dilakukan dengan cara deduktif. Dimana setiap makna yang berhasil dianalisis dari data yang terkumpul saat penelitian ini, bertujuan untuk mendapatkan kesimpulan tahap akhir. 


\section{Hasil Penelitian dan Pembahasan}

\section{Pemanfaatan Media dalam Pencarian Informasi mengenai Program Studi di Perguruan Tinggi Negeri}

Sebelum membahas mengenai sikap siswa SMA Kelas XII di Kota Bandung terhadap informasi mengenai Program Studi di Perguruan Tinggi Negeri yang diperoleh melalui berbagai media informasi. Berikut akan dipaparkan terlebih dahulu mengenai jenis-jenis media yang digunakan oleh siswa SMA kelas XII dalam memperoleh informasi mengenai Program Studi di Perguruan Tinggi Negeri.

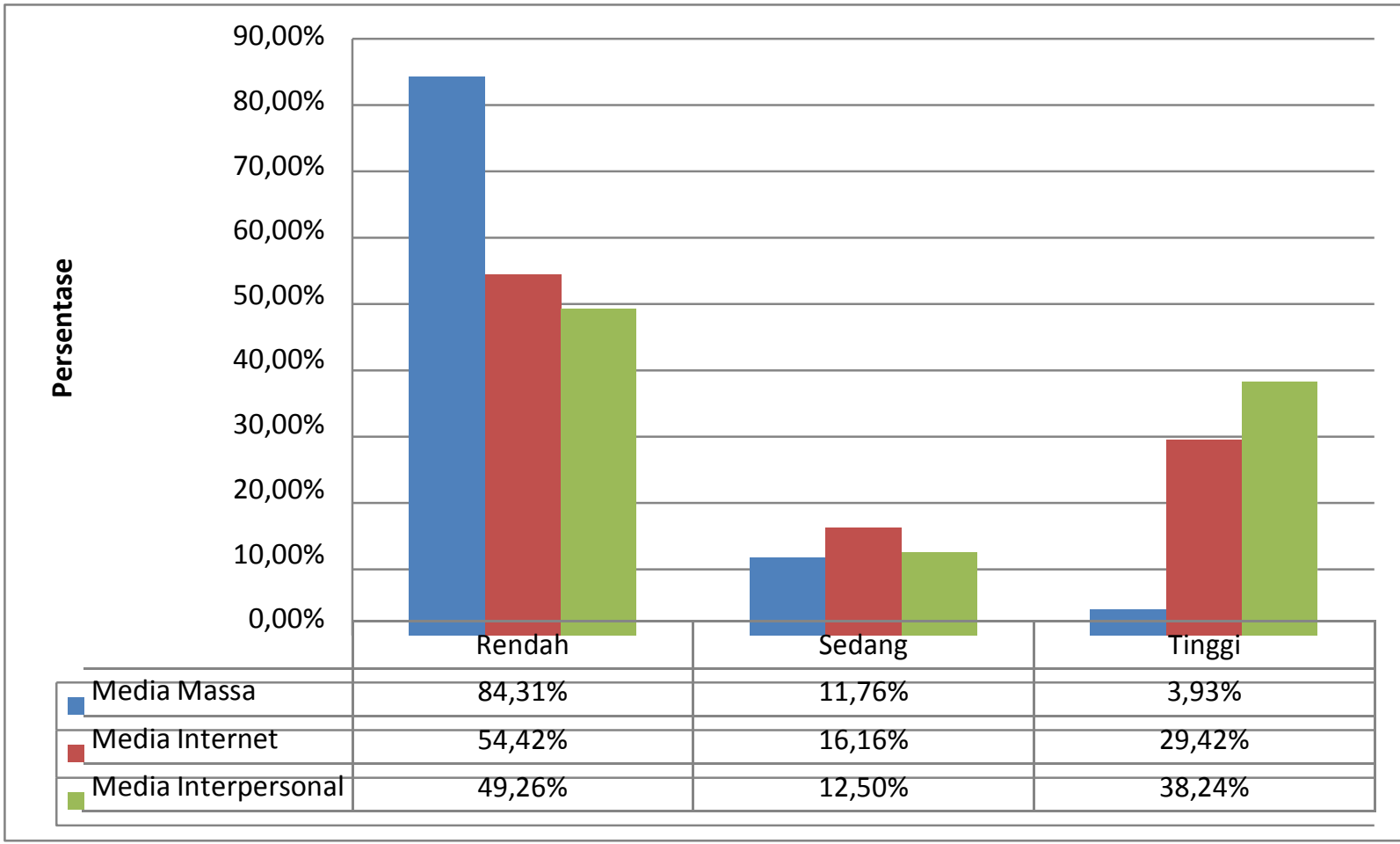

Diagram 1

Pemanfaatan Media dalam Pencarian Informasi mengenai Program Studi di Perguruan Tinggi Negeri

Dari tiga media yang dipaparkan dalam Diagram 1, terlihat bahwa media interpersonal memiliki porsi yang tinggi sebagai media yang dijadikan sumber referensi oleh siswa SMA kelas XII dalam pencarian informasi mengenai program studi di perguruan tinggi negeri. Sebesar 38,24\% menyatakan bahwa media interpersonal berada pada kategori tinggi. Teman dan alumni merupakan dua pihak yang dianggap memberikan andil yang paling besar dalam memberikan informasi mengenai program studi di perguruan tinggi negeri, yaitu sebesar $44 \%$. Sedangkan orang tua atau kerabat dekat merupakan pihak yang turut menentukan pemilihan 
program studi yang akan dipilih oleh siswa SMA ketika akan melanjutkan studi ke jenjang sarjana. Kemudian, guru merupakan pihak yang dianggap mampu memberikan informasi yang tepat mengenai program studi, sehingga bisa diberikan penilaian mengenai tingkat kecocokan program studi dengan minat dan kemampuan dari siswa SMA yang akan memilihnya.

Sebanyak 29,42\% siswa SMA Kelas XII menggunakan media internet sebagai media untuk mencari informasi mengenai program studi di perguruan tinggi negeri. Walaupun menunjukka angka yang tinggi, tetapi tetap saja masih berada di bawah media interpersonal. Hal ini dikarenakan, media-media sosial lainnya, selain website, belum dimanfaatkan secara maksimal oleh siswa SMA kelas XII dalam pencarian informasi mengenai program studi. Hal tersebut dikarenakan memang pihak perguruan tinggi negeri belum banyak yang menggunakan media sosial seperti facebook, instragram, dan twitter sebagai media informasi maupun promosi. Padahal data menunjukkan bahwa penguna dari ketiga media sosial tersebut jumlahnya sangat banyak. Ini menjadi peluang bagi program studi untuk dapat memaksimalkan fungsi dari media-media sosial tersebut, yang dapat diintegrasikan penggunaan dengan website resmi yang dimiliki oleh program studi.

Walaupun secara umum, media interpersonal mendapatkan proporsi yang tertinggi, tetapi secara khusus, media yang paling besar pemanfaatannya dalam proses pencarian informasi adalah website. Dimana sebanyak $79 \%$ menyatakan bahwa website berada ada kategori tinggi. Website yang secara resmi dibuat oleh perguruan tinggi negeri memberikan informasi yang lengkap mengenai semua program studi yang ada ditawarkan. Terlebih lagi, program studi pun membuat website resmi, yang berisikan informasi yang lebih khusus dan lebih detail. Dimana seluruh website program studi tersebut terhubung dengan website perguruan tinggi negeri. Hampir setiap program studi memiliki staf yang khusus untuk mengelola website, sehingga setiap informasi dapat langsung dipublikasikan dengan cepat dan tepat. Kredibilitas pesan yang disampaikan dianggap sangat tinggi karena website tersebut resmi dikeluarkan oleh perogram studi yang bersangkutan.

Menariknya adalah media massa baik televisi, surat kabar, maupun radio sudah tidak memiliki peranan yang signfikan dalam menambah informasi mengenai program studi bagi siswa SMA. Data menunjukkan bahwa sebesar $84,31 \%$ dari siswa SMA Kelas XII di Kota Bandung menyatakan bahwa tidak pernah menggunakan media massa dalam mencari informasi mengenai program studi di perguruan tinggi negeri. Karakteristik media massa yang mampu menyebarkan informasi secara massif kepada orang-orang yang tersebar di berbagai 
tempat, tidak berpengaruh pada konteks penyebaran informasi mengenai program studi di perguruan tinggi negeri.

\section{Sikap Siswa SMA terhadap Informasi mengenai Program Studi di Perguruan Tinggi Negeri}

Setelah mengetahui bagaimana bentuk pemanfaatan media yang dilakukan oleh siswa SMA kelas XII untuk mencari informasi mengenai program studi di perguruan tinggi negeri, maka pada bagian ini akan dipaparkan mengenai bagaimana sikap siswa SMA Kelas XII terhadap informasi tersebut. Dalam penelitian ini, sikap dapat dilihat sebagai keadaan di dalam diri seorang siswa SMA kelas XII yang mampu menggerakkan siswa tersebut untuk bertindak atau berbuat dengan perasaan tertentu dalam menanggapi berbagai informasi yang mereka dapatkan dari berbagai media mengenai program studi di perguruan tinggi negeri. Sikap siswa SMA Kelas XII dapat memberikan kesiapan merespon secara positif ataupun negatif terhadap informasi yang telah didapatkan.

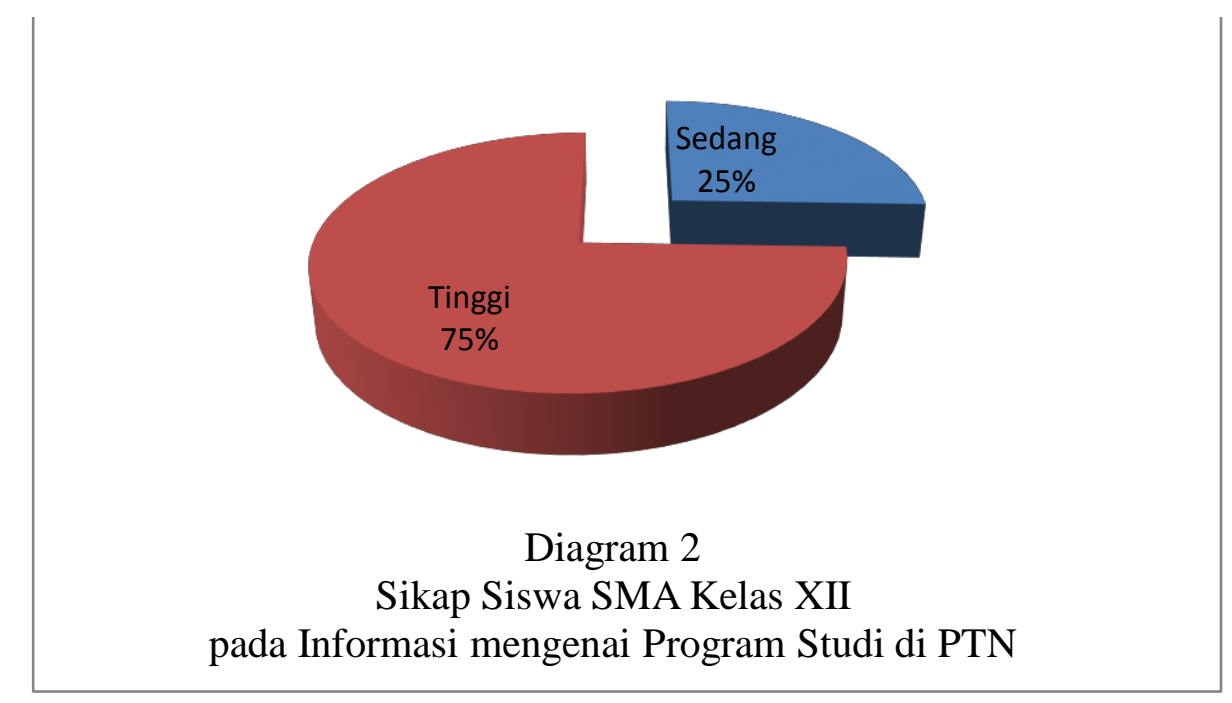

Sarnoff (dalam Sarwono, 2000) menyatakan sikap sebagai kesediaan untuk bereaksi (disposition to react) secara positif (favorably) atau secara negatif (unfavorably) terhadap obyek - obyek tertentu. Sedangkan La Pierre (dalam Azwar, 2003) memberikan definisi bahwa sikap merupakan suatu pola perilaku, tendensi atau kesiapan antisipatif, predisposisi untuk menyesuaikan diri dalam situasi sosial, atau secara sederhana, sikap adalah respon terhadap stimuli sosial yang telah terkondisikan. Lebih lanjut Soetarno (1994) memberikan definisi sikap adalah pandangan atau perasaan yang disertai kecenderungan untuk bertindak terhadap obyek tertentu. Sikap senantiasa diarahkan kepada sesuatu artinya tidak ada sikap 
tanpa obyek. Sikap diarahkan kepada benda-benda, orang, peritiwa, pandangan, lembaga, norma dan lain-lain.

Sikap muncul dikarenakan adanya sebuah objek. Objek dalam penelitian ini adalah informasi mengenai program studi di perguruan tinggi negeri. Diagram 2 menggambarkan bahwa sikap dari 75\% siswa SMA di Kota Bandung berada pada kategori tinggi, yang berarti reaksi positif ditunjukkan oleh siswa SMA di Kota Bandung pada informasi mengenai program studi di perguruan tinggi. Reaksi positif muncul dikarenakan tingat kepentingan dari informasi tersebut dianggal tinggi oleh siswa SMA di Kota Bandung.

Rahmat (2001: 40) menyatakan bahwa sikap dibangun oleh tiga komponen yang ada di dalam diri manusia. Komponen tersebut terdiri dari komponen kognitif, afektif, dan konatif. Sikap siswa SMA yang berarti kecenderungan siswa SMA untuk berperilaku pasti dipengaruhi oleh ketigaa komponen tersebut. Menurut Crutchfield \& Ballachey (1982), komponen kognitif merupakan komponen dari suatu sikap terdiri dari keyakinan-keyakinan individu mengenai suatu objek. Keyakinan tersebut muncul dari pengalaman individu, pengamatan, serta informasi yang diperoleh oleh individu. Informasi mengenai program studi di perguruan tinggi negeri didistribusikan melalui berbagai media yang telah dipaparkan pada bagian sebelumnya. Komponen kognitif dari 74\% siswa SMA di Kota Bandung berada pada kategori tinggi. Hal tersebut menunjukkan bahwa berbagai informasi yang dibutuhkan oleh siswa SMA di Kota Bandung sudah bisa mereka dapatkan dari berbagai media informasi, baik media informasi yang bersifat interpersonal maupun media internet. Pengetahuan yang diperoleh dari informasi melalui media tersebut, ditambah dengan pengetahuan yang telah dimiliki sebelumnya mengenai program studi di perguruan tinggi negeri serta pengalaman yang pernah mereka dapatkan saling berintegrasi dan menjadikan komponen kognitif siswa SMA di Kota Bandung masuk pada kategori tinggi.

Beberapa informasi yang diperoleh siswa SMA Negeri di Kota Bandung adalah informasi mengenai gambaran perkuliahan di program studi di perguruan tinggi negeri, cara mendaftar di program studi, prospek kerja, serta lokasi dan sarana prasarana yang terdapat di program studi perguruan tinggi yang mereka minati. Berbagai informasi yang didistribusikan melalui berbagai media tersebut diterima dengan baik oleh siswa SMA di Kota Bandung, dan turut membangun sikap positif dari siswa SMA di Kota Bandung terhadap informasi mengenai program studi di perguruan tinggi negeri.

Selain komponen kognitif, komponen afektif juga membangun sikap dari siswa SMA di Kota Bandung. Komponen afektif dari siswa SMA di Kota Bandung mengacu pada emosi 
yang terkait dengan informasi mengenai program studi di perguruan tinggi negeri. Apakah siswa SMA Negeri di Kota Bandung menganggap informasi mengenai program studi di perguruan tinggi negeri itu sesuatu yang menyenangkan / disukai atau tidak. Berdasarkan hasil penelitian, komponen afektif dari $85 \%$ siswa SMA di Kota Bandung berada pada kategori tinggi. Hal tersebut menunjukkan bahwa informasi mengenai program studi di perguruan tinggi negeri sangat disukai oleh siswa SMA di Kota Bandung.

Siswa SMA di Kota Bandung menyukai informasi mengenai program studi yang sesuai dengan minat dan bakatnya. Mereka juga meyakini bahwa kemampuan dan keterampilan yang dimiliki oleh siswa SMA di Kota Bandung akan bertambah apabila mengikuti perkuliahan di program studi yang mereka pilih. Kemudahan mendapatkan informasi mengenai program studi melalui berbagai media, terutama media sosial juga menambah rasa senang siswa SMA di Kota Bandung. Berbagai pembicaraan positif mengenai program studi yang dipilih semakin memperkuat komponen afektif dari siswa SMA di Kota Bandung.

Komponen yang terakhir adalah komponen konatif. Komponen konatif dari suatu sikap mencakup semua kesiapan perilaku (behavioral readiness) yang terkait dengan sikap. Jika seorang individu memiliki sikap positif terhadap objek tertentu, dia akan memiliki kecenderungan untuk membantu atau mengganjar atau mendukung obyek itu, jika dia bersikap negatif, dia akan cenderung mencelakai atau menghukum atau menghancurkan objek tersebut. Sikap positif yang ditunjukkan oleh siswa SMA di Kota Bandung terhadap informasi mengenai program studi negeri, ditunjukkan dengan keputusan mereka untuk memilih program studi yang sesuai dengan minat dan bakatnya. Keputusan mengenai pemilihan program studi tersebut dilakukan setelah siswa SMA di Kota Bandung setelah berdiskusi dan mendapatkan rekomendasi dari guru di sekolah dan guru di tempat bimbingan belajarnya. Setelah siswa SMA di Kota Bandung memutuskan untuk memilih salah satu perguruan tinggi, mereka berusaha untuk lulus dan dapat diterima menjadi mahasiswa di program studi yang telah dipilihnya. Maka dari itu mereka berusaha belajar semaksimal mungkin untuk dapat lolos seleksi masuk ke program studi yang dipilihnya.

\section{Kesimpulan}

Secara khusus, media yang dimanfaatkan oleh siswa SMA dalam pencarian informasi mengenai program studi adalah website. Website dianggap sebagai media yang terpercaya dalam memberikan informasi yang tepat dan lengkap mengenai program studi yang akan 
dipilih oleh siswa SMA saat mereka akan melanjutkan pendidikan ke jenjang yang lebih tinggi. Tetapi secara umum, media interpersonal masih memberikan kontribusi yang besar dalam pencaran informasi program studi oleh siswa SMA. Teman dan alumni adalah dua pihak yang dianggap mampu memberikan informasi tambahan yang dapat memperkuat informasi yang telah diperoleh melalui website. Sedangkan orang tua dan guru dianggap sebagai pihak yang mampu memberikan keyakinan mengenai program studi yang akan dipilih oleh siswa SMA. Informasi yang disampaikan melalui berbagai media tersebut turut membangun sikap positif dari siswa SMA di Kota Bandung terhadap peguruan tinggi negeri di Indonesia. Siswa SMA di Kota Bandung memperoleh informasi yang sangat membantu mereka dalam memtuskan program studi yang akan mereka pilih.

\section{DAFTAR PUSTAKA}

Azwar, Saifuddin. 1997. Metode Penelitian. Yogyakarta: Pustaka Pelajar. 2003. Sikap Manusia, Teori, dan Pengukurannya. Yogyakarta : Pustaka Pelajar.

Krech, D., Crutchfield, R.S. \& Ballachey, E.L. 1962. Individual in Society, London: McGrawHill

Margono. 2010. Metodologi Penelitian Pendidikan. Jakarta: Rineka Cipta.

Rakhmat, Jalaluddin. 2001. Psikologi Komunikasi. Bandung: Remaja Rosdakarya. 2001. Metode Penelitian Komunikasi. Bandung: Remaja Rosdakarya. Sarwono. 2000. Teori-Teori Psikologi Sosial. Jakarta: Raja Grafindo Persada. Soetarno. 1994. Psikologi Sosial. Yogyakarta: Kanisius 